\title{
PV-Wind-Diesel System for Energy Supply on Remote Area Applied for Telecommunication Towers in Comoros
}

\author{
Fahad Maoulida1,2, Djedjig Rabah², Mohammed El Ganaoui², Kassim Mohamed Aboudou1,2* \\ ${ }^{1}$ Laboratory of Energetic LERMAB, IUT Henri Poincaré, 186 Route de Lorraine Cosnes-et-Romain Longwy, University of \\ Lorraine, Nancy, France \\ ${ }^{2}$ Energy and Applied Mecanics Laboratory, LEMA, Physics and Mathematics Department, Faculty of Sciences and Techniques, \\ University of Comoros, Moroni, Comoros \\ Email: ^kassim2005k@gmail.com
}

How to cite this paper: Maoulida, F. Rabah, D., El Ganaoui, M. and Aboudou, K.M. (2021) PV-Wind-Diesel System for Energy Supply on Remote Area Applied for Telecommunication Towers in Comoros. Open Journal of Energy Efficiency, 10, 50-72.

https://doi.org/10.4236/ojee.2021.102004

Received: March 6, 2021

Accepted: June 8, 2021

Published: June 11, 2021

Copyright (c) 2021 by author(s) and Scientific Research Publishing Inc. This work is licensed under the Creative Commons Attribution International License (CC BY 4.0).

http://creativecommons.org/licenses/by/4.0/

\begin{abstract}
The Comoros is an archipelago in the Indian Ocean located in the Mozambique Channel between the African continent and Madagascar. Geographically Comoros is composed of four islands: Grande Comores, Anjouan, Mohéli and Mayotte (under French administration). Apart from Mayotte, the others three independent islands commonly known as the Union of the Comoros are suffering from energy stress since their independence year 1975 until nowadays. The energy supplied and distributed by the national electricity company, SONELEC produced by diesel engines, is not stable with so much load shedding all the time. This instability energy leads to a lack of a phone network in some telecommunications towers connected to grid. The majority of telecommunications towers are located in rural areas not connected to grid and running on diesel generators, which once again leads to a problem with the telecommunications network when diesel engines fail. The two competing companies which operate in the field of telecommunications in the Comoros, namely Comores Télécom, a national public company and Telma, the private one, are still unable to ensure the provision of the telecommunications network on a regular basis. This is why we propose in the present work, a sizing of hybrid system composed essentially of a diesel generator, a wind turbine and a photovoltaic solar system with storage in batteries for supplying telecommunications towers in order to permanently ensure the provision of the telecommunications network for the well-being of the population. Our future energy must be based on non-polluting energies with significant resources. Renewable energies are the best candidates but with intermittent production especially in rural areas not connected to the national electricity grid whose energy demand is more important to meet the needs of the population. The
\end{abstract}


aim of this work is the sizing of a hybrid system composed of a diesel generator, a wind turbine and a photovoltaic solar system with storage in batteries for supplying telecommunications towers located in rural areas in the Comoros. In fact, to verify the performance of the hybrid system, a numerical study has been carried out with the HOMER 2.68 Beta software using meteorological data from the Comoros. The results obtained show that this hybrid combination is more profitable in the margin of economic cost and environmental assessments with a less expensive investment. These results also show a better optimization of Wind/PV/Battery of the hybrid system used, satisfying the demand and contributing to the preservation of the environment to fight against climate change with a low cost of energy.

\section{Keywords}

Hybrid System, Renewable Energy, HOMER, Meteorological Data, Telecommunication, Towers, Rural Area

\section{Introduction}

The increase of the price of oil and the depletion of fossil fuel resources are driving the current world towards energy transition, therefore the exploitation of renewable energy resources such as solar, wind hydroelectricity and geothermal energy, in order to guarantee permanent energy availability at a lower cost. Indeed, due to population growth global warming and the increase in soil and water pollution, the use of renewable energies is considered to be an alternative solution. In Comoros Islands, the exploitation of renewable energy resources is not too developed despite their abundance. We can note the existence of a tropical climate with an average annual temperature around of $29^{\circ} \mathrm{C}$, an average annual win speed estimated at $5 \mathrm{~m} / \mathrm{s}$, the existence of an active volcano that can be operated with a power evaluated at $30 \mathrm{MW}$ as well as exploitable rivers for hydroelectricity.

Comoros Island is much more affected by the electricity problem due to a permanent lack of energy caused by failing power plants. The rural areas where the telecommunication towers are installed are still affected by the lack of energy supplied by engine-based diesel generators. The power supply of telecommunication towers by hybrid energy (PV/Wind/Gens) can reassure the permanence of energy in order to guarantee the telecommunication network in Comoros.

Mohamad Shahrizal et al. [1] have conducted a feasibility analysis of stand-alone renewable energy supply for telecommunication towers using Homer in Malaysia with a solar photovoltaic (PV) system. The specific of their system is that the electric power generation system, which consists of solar PV system hybrid with diesel generator, has the ability to provide 24 hours electricity to the load.

In order to optimize the system design, their work compares a wide range of equipment with different constraints and sensitivities. 
Their results show that the system offers better reliability, efficiency, flexibility of planning and environmental benefits compared to the diesel generators systems by saving the environment from the burning of fossil fuels.

A load profile of telecom towers in India and potential renewable energy power supply configurations have been studied by Niranjan et al. [2]. The configuration included photovoltaic (PV) and wind based renewable energy technologies. Indeed, the electrical load and existing power supply options for telecom towers, and status of power availability in 21 selected locations across the country, are presented. Levelized cost of electricity (LCOE) is estimated for various potential power supply configurations.

Authors show that the configuration with solar PV array, wind, electric grid, Diesel Gens set and a battery, is found to be lowest LCOE when the power is unavailable continuously for this configuration.

A comparison of this system with the options of extension to the grid and diesel generator system has been realized by the authors. Their analysis shows that the hybrid energy system which consists of $5 \mathrm{~kW} \mathrm{PV}, 1$ wind turbine, 19 units of battery and $4 \mathrm{~kW}$ converter is the most optimum hybrid system. A review of energy management strategies in hybrid renewable energy systems has been studied by Olatomiwa et al. [3] with special attention to energy management strategies used in smart grids. The authors have adopted an approach that takes into consideration the feeding of a hybrid system on renewable energies in rural areas without connection and with connection to the national electricity grid. Their main recommendations suggest that developing energy and the loads connected directly to these sources is recommended. For this, it will be necessary to specify how to measure the heat of the energy generated by the distributed production sources as well as the loads. Optimization of hybrid systems for remote area electrification in Comoros and design of a hybrid system for the power supply of a telecommunications tower in the Comoros have been studied by Kassim et al. and Fahad et al. [4]-[12] with HOMER software tool by combined PV/Diesel system and PV/Wind/Diesel system. Their results show that PV/Diesel/Wind system is more profitable economically and diminishes greenhouse gas emissions for protection of environment. An optimum off-grid PV/Diesel hybrid energy system for rural electrification in Iraq has been conducted by Ali Saleh and Sara [13] with HOMER software in order to implement techno-economic and environmental feasibility. Analysis study was presented to estimate the standalone electrification for comparison with grid expansion. Their results show that the off-grid PV/Diesel system is found to be more frugal than grid expansion. In the same aspect, Saima et al., [14] have carried out a techno-economic analysis of hybrid grid connected PV/Wind system in Pakistan using meteorological database simulated by HOMER software taking in to account of daily, monthly and annually profiles of solar irradiance, temperatures and wind speeds. Different locations were analyzed by authors specially for different component of the system in order to respect the least calculated Net Present Coast (NPC). There are results show that most appropriate component was suggested for loca- 
tion giving the least NPC for an optimization of hybrid system. Godson et al. [15] was carried out a solar PV-Wind hybrid power generation system technology for production of electricity. Among advantages of the system are optimum utilization of resources and improve efficiency suitable for industries, domestics and remote areas. The costs of micro-grid developed at a remote area community in Brazil located in amazon region are investigated by Tiago and Luciana, [16]. Authors show that these costs can be minimized with realizing of the best combination of hybrid energy system. The cost of energy for different demands was studied by the authors. There results show that the substitution of wind turbines by adding more photovoltaic panels is realized for reduction of cost of energy. It has benne shown that in this case annual dispends can be reduced of $54 \%$ for the best optimal configuration.

A power flow control of photovoltaic-wind-battery Hybrid Renewable Energy System (HRES) for stand-alone application is presented here by Somnath Das and Akella [17] to balance the power generation and load power. A control strategy is implemented with fuzzy logic controller for smoothing of the power fluctuation and at the same time to maintain the battery state of charge (SOC) with in allowable limits. Their results show that in spite of sudden load changes and changes in the power generation, the power balance between the supply and demand effectively maintained by the proposed fuzzy logic based controller (FLC). The power fluctuation is suppressed and supply a good quality power while maintaining SOC within limits. An analysis of hybrid power generation systems for a residential load was conducted by Bartosz Ceran et al. [18]. The authors present results of an energetic and economic analysis of a hybrid power generation system (HPGS) which utilises photovoltaic modules, wind turbines, fuel cells and an electrolyzer with hydrogen tank working as the energy storage. Their analysis was carried out for three different residential loads, local solar radiation and local wind speed, based on the real measurement values. This analysis shows the optimal solution and the limits of the investment costs required for the system construction. The presented results confirm the effectiveness of the proposed approach, which could be assumed as a very useful tool in the design and analysis of a hybrid power generation system. Moh'd and Khaled [19] were investigated for a solar hybrid system for power generation and water distillation. A mathematical model under steady-state conditions has been introduced by the authors and improved to investigate the system performance. Their works show that an increase of solar radiation and ambient temperature or a decrease in wind velocity affect positively the distillation rate, still efficiency, system efficiency, and output power. The results of the simulation have been verified by comparing them with published theoretical and experimental results and the comparison shows very good agreement. Sompol Kohsri and Boonyang Plangklang [20] have presented an application energy management system and control system for smart renewable energy power generation. The simulation program is Homer Program to test the functionality and performance evaluation of the system which can be simulated that the designed system is working prop- 
erly. The system consists of a PV Size $1.8 \mathrm{~kW}_{\mathrm{P}}$, Generator Size $2 \mathrm{~kW}$ and a Battery capacity size of $18.3 \mathrm{kWh}$. From the experiment, their results show that the system is working properly and stably as designed.

Recently, Fahd and Abdulhakim [21] were conducted a technico-economic evaluation and optimization of a grid connected PV and Wind generating system for Riadh City in Saudi Arabia. Their work explores the feasibility of supplying electricity from a hybrid power system (HPS) comprising wind/photovoltaic (PV) and batteries. Taking into account residential buildings that consume the largest portion of energy in Saudi grid, Saudi Arabia, Riyadh is the preferred city with distinctive geographical and climatic conditions. The economic analysis is carried out by applying HOMER software on the basis of net present cost (NPC), energy cost (COE) and the renewable fraction for all situations. In addition, to specify the effect of fuel costs on the scheme, sensitivity tests are carried out by considering two separate tariff rates for residential consumers. The results of the economic analysis show that current tariff is not economic to use HSP under warm and temperate climate conditions compare to using electricity from grid and the expected forecasted tariff shows it's economic to use HSP compare to grid electricity. Husain and Djawad [22] has been studied an assessment of wind power potential at Eastern-Jerusalem in Palestine. The authors show that their results can be applied to all study using surface measurements at precise locations at different altitudes above the ground.

The objective of the present study is to evaluate the performance of an autonomous system of electric power generation, coupling a PV array, a wind turbine, and a diesel generator with a storage system made up of batteries to meet the demand of the electric charge for the supply of a telecommunications tower located in rural areas in the Comoros.

\section{Sizing of the Hybrid Energy System}

We present in Figure 1 the sizing of the hybrid system made from the HOMER commercial software tool. The studied system consists of a wind generator type BWC Excel-R, a photovoltaic network system. The electrical load [23] relating to telecommunication tower, whose value is $63 \mathrm{kWh} / \mathrm{j}$ with a peak of $3.8 \mathrm{~kW}$, is powered by batteries tank type $\mathrm{H} 600$ with a nominal voltage of $12 \mathrm{~V}$ and a nominal capacity of 200 Ah through combined by a nominal power inverter of 1.2 $\mathrm{kW}$ that converts the DC power stored in the battery tank into alternating current AC to a standard voltage level and frequency, and then supply it to the load. The control of their charge is ensured by a charge controller.

\subsection{Description of Diesel Generator and Diesel Fuel Characteristics of the System}

In the present study the Diesel Generator (DG) type AC can generate at nominal power. Thus, the excess energy observed can participate to charge a battery in general. Indeed, DG is designed in such a way that it runs between $75 \%$ and $100 \%$ of the evaluation in $\mathrm{kW}$ running with battery or other renewable energy 


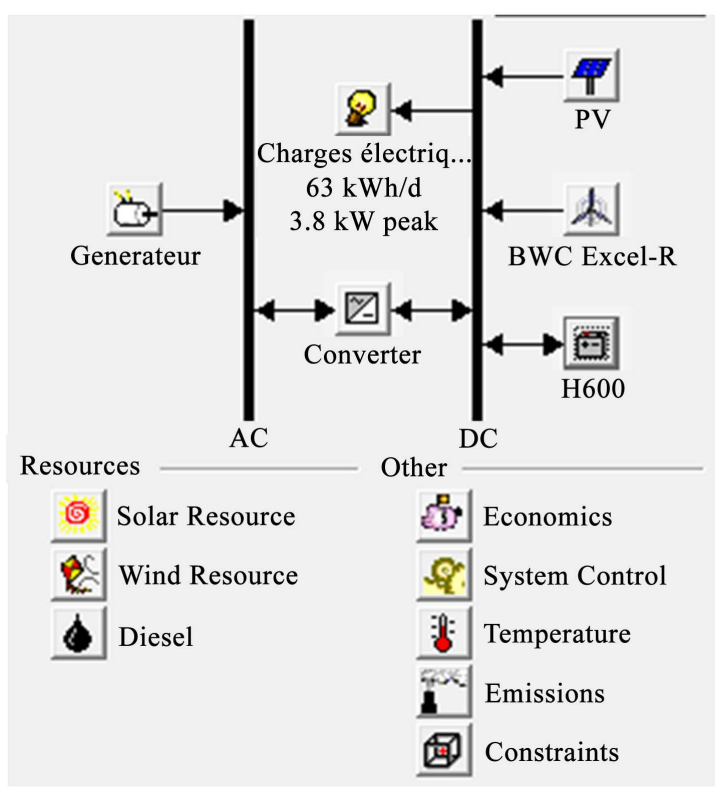

Figure 1. HOMER implementation of the hybrid energy system.

systems. In order to make a best comparison between the system with a feasibility system one we have included it in the simulation. Lifetime (operation hours) is 35,000 hrs with minimum load ration of $30 \%$. Generated DG $\left(E_{D G}\right)$ with nominal power $\left(P_{D G}\right)$ is given by [4] [24]:

$$
E_{D G}=P_{D G} * \eta_{D G} * t
$$

where $\eta_{D G}$ is the yield of the generator and $t$ the working time.

For the present study, the costs of capital for diesel generator are such that $\$ 400 / \mathrm{kW}$. Replacement, operation and maintenance costs are assumed to be $\$ 350 / \mathrm{kW}$ and $(\$ 0.02 / \mathrm{hr} / \mathrm{kW})$ respectively.

In Table 1 we present the characteristics of diesel fuel.

\subsection{Renewable Resources}

Both solar energy and wind resources are the principal characteristics of renewable resources in this study. Indeed, we conducted a sensitivity analysis for suitable results in the study area for energy supply of telecommunications towers.

\subsection{Solar Energy}

The average daily sunshine Northern Ngazidja is estimated at 10 hours' time per day with an average power of $5.29 \mathrm{~kW} / \mathrm{m}^{2} / \mathrm{d}$ of production. Ngazidja meteorological data between 1961 and 2018 shows an effective sunshine whatever the month or season [4] [5] [25]. The Comorian islands also receive a very important solar radiation rate. These values show that the country has a high level of solar radiation able of supplying photovoltaic and solar thermal installations. Indeed, HOMER software tool retrieves directly the clearness index via the information present on the latitude of the site under investigation for telecommunications towers (Figure 2). 


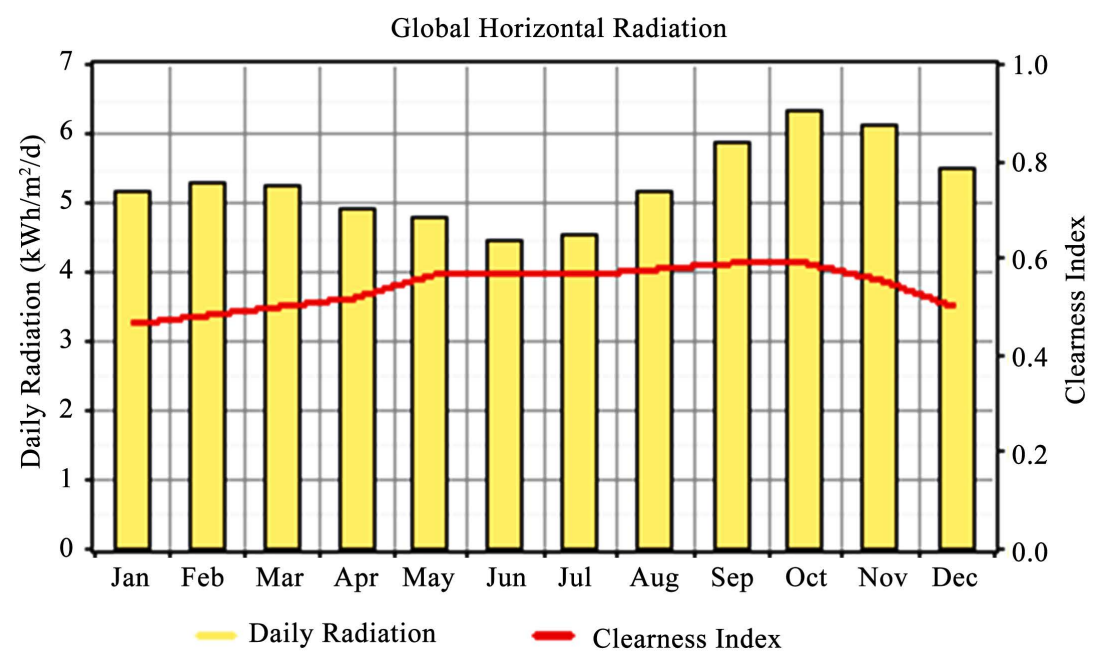

Figure 2. Average daily radiations of earth.

Table 1. Physical characteristics of the diesel fuel.

\begin{tabular}{ccc}
\hline Fuel properties & Value \\
\hline Lower heating value & & $43.2 \mathrm{MJ} / \mathrm{kg}$ \\
Density & & $820 \mathrm{~kg} / \mathrm{m}^{3}$ \\
Carbon content & $88 \%$ \\
Sulfur content & & $0.33 \%$ \\
& Fuel cost $\max \$ 0.99$ & \\
& Fuel cost $\min \$ 0.79$ & \\
\hline
\end{tabular}

\subsection{Wind Speed Analysis}

Figure 3 chows the monthly average wind speeds at the site areas. We observe that wind speeds are higher in part of the summer months as shown in this plot (Jun-July-August and September). The peak is pronounced on July. This clearly reflects that turbine wind would produce appreciably more energy during the summer months as compared to others months. In the other hand, the overall average wind speed is $5 \mathrm{~m} / \mathrm{s}$. In fact, the data also show that there is considerable variation of monthly average wind speed from one month to another month.

These variations demonstrate how the monthly energy output from wind energy conversion system could be subjected to considerable differences. Time step is set at $60 \mathrm{mn}$, altitude above the sea level is $60 \mathrm{~m}$ with an anemometer height of $10 \mathrm{~m}$ for 16 hour of peak wind speed. The 1-hour autocorrelation factor is 0.967 and diurnal pattern strength is set at 0.09 . Figure 4 presents the frequency distribution hourly of wind speed at Ngazidja in Comoros. The potential of the study site in rural areas was evaluated from this frequency distribution hourly wind speed. It can be seen that wind speeds are above $5.56 \mathrm{~m} / \mathrm{s}$ at around $70 \%$ of the time during the year, which shows that wind energy will produce about $75 \%$ of the total output of the hybrid system of the time with a constant Weibull value of $\mathrm{k}=2.10$. 


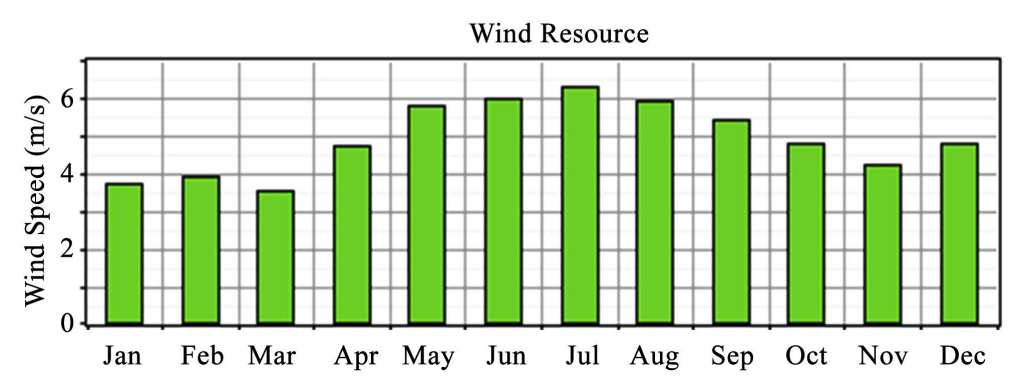

Figure 3. Average monthly wind at the site of telecommunications tower implantation.

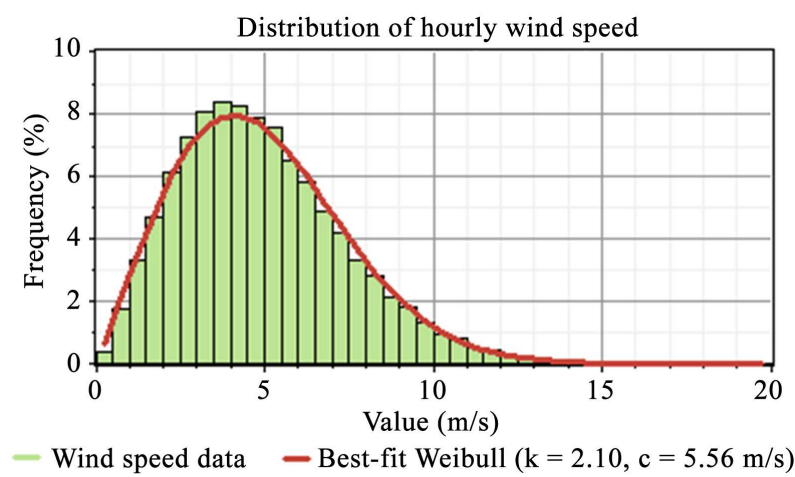

Figure 4. Frequency distribution hourly wind speed.

\section{Hybrid System Components}

The energy system consists of a diesel generator, wind turbine combined by a photovoltaic module, a storage battery and a power converter. The number of units to be taken into account, the cost, the hours of operation must be declared in the HOMER software for each of these components. In fact, the details of these components are explained in the following parts.

\subsection{Photovoltaic Array}

In this present study, $1 \mathrm{~kW}$ solar energy system's installation, and replacement costs are taken as $\$ 800$ and $\$ 700$, respectively. Five different sizes are considered, which are (0, no PV module, 25, 50, 75 and $100 \mathrm{~kW})$. The lifetime of the PV arrays is taken as 25 years and no tracking system is included in the PV system. Technical parameters and costs of Photovoltaic are resented in Table 2 for more details.

\subsubsection{Incident Radiation on the PV Array}

The incident solar inclination on the PV array is calculated from the following equations given below [4]:

$$
\delta=23.45^{\circ} \sin \left(360^{\circ} \frac{284+n}{365}\right)
$$

where $n$ is the day of the year [a number 1 through 365]. In the other hand, an hour angle is given as the time of day affects the location of the sun sky. It can be calculated from the following equation: 
Table 2. Technical parameters of PV.

\begin{tabular}{cc}
\hline Parameters & Value \\
\hline Derating factor & $80 \%$ \\
Nominal operating cell temperature & $45^{\circ} \mathrm{C}$ \\
Temperature coefficient of power & $-0.46 \% /{ }^{\circ} \mathrm{C}$ \\
Efficiency at standard test condition & $14.2 \%$ \\
Ground reflectance & $25 \%$ \\
Tracking system & No tracking \\
\hline
\end{tabular}

$$
\omega=\left(t_{s}-12 \mathrm{hr}\right) \times 15^{\circ} / \mathrm{hr}
$$

where $t_{s}$ is the solar time. It is important to notice that $t_{s}$ is $12 \mathrm{hr}$ at solar noon, and $13.5 \mathrm{hr}$ ninety minutes later. Equation (3) shows that that the sun moves across the sky at 15 degrees per hour. HOMER performs the calculations assuming that all time-dependent data such as solar radiation and electric charge are not given in solar times, but rather in civil time also known as local standard time calculated from the equation below:

$$
t_{s}=t_{c i}+\frac{\lambda}{15^{\circ} / \mathrm{hr}}-Z_{c}+E
$$

where $t_{c i}$ is the civilian time in hours and $\lambda$ is the longitude, $Z_{c}$ is the time zone corresponding to the hours east of GMT and $E$ is the hourly equation.

\subsubsection{Photovoltaic Cell Temperature}

We have to notice that the temperature of the photovoltaic cell is defined as being the temperature of the surface of the photovoltaic array. The energy balance for the PV array is given by [4] [26]:

$$
\tau \alpha G_{T}=\eta_{c} G_{T}+U_{L}\left(T_{c}-T_{a}\right)
$$

where $\tau$ is the solar transmittance of any cover on the photovoltaic array, $\alpha$ the solar absorption of the photovoltaic array, $G_{T}$ the solar radiation hitting the photovoltaic array, $\eta_{c}$ the electrical conversion efficiency of the photovoltaic array, $U_{L}$ the heat transfer coefficient to the environment, $T_{c}$ the temperature of the PV cell and $T_{a}$ the ambient temperature.

The equation above (5) indicates that there is a balance between the solar energy absorbed by the PV array and the electrical output plus the heat transfer to the environment. We can solve this equation for the temperature of the photovoltaic cell array:

$$
T_{c}=T_{a}+G_{T}\left(\frac{\tau \alpha}{U_{L}}\right)\left(1-\frac{\eta_{c}}{\tau \alpha}\right)
$$

\subsection{Wind Energy Conversion System}

The variation of the wind speed gives us an idea about the wind turbine capacity energy that could be produced. Therefore, the wind turbine index is generally 
much higher compared to the average electrical load. In this study the model BWC Excel-R was considered. It has a rated power of $7.5 \mathrm{~kW}$ DC. The cost of a unit is estimated at $\$ 5000$ while replacement and maintenance costs are taken in $\$ 3000$ and $\$ 15$ per year. Indeed, to allow the simulation program to check optimization solution, six different quantities were considered (0, no turbine, 1, 2, 3, 4 or 5 units) with a lifetime turbine wind of 25 years and hub height is $25 \mathrm{~m}$.

Concerning the equations governing the wind system, HOMER calculates the power output of the wind turbine in each time step. This entails a three-step process to first calculate the wind speed at the hub height of the wind turbine, then to calculate how much power the wind turbine would produce at that wind speed at standard air density, then to adjust that power output value for the actual air density.

In each time step, HOMER calculates the wind speed at the hub height of the wind turbine using the inputs you specify in the Wind Resource Inputs window and the Wind Shear Inputs window. If you choose to apply the logarithmic law, HOMER calculates the hub height wind speed using the following equation:

$$
U_{\text {hub }}=U_{\text {anem }} \frac{\ln \left(\frac{Z_{\text {hub }}}{Z_{0}}\right)}{\ln \left(\frac{Z_{\text {anem }}}{Z_{0}}\right)}
$$

where, $U_{h u b}$ is the wind speed at the hub height of the wind turbine $[\mathrm{m} / \mathrm{s}], U_{\text {anem }}$ the wind speed at the anemometer height $[\mathrm{m} / \mathrm{s}], Z_{h u b}$, the hub height of the wind speed $[\mathrm{m}], Z_{\text {anem }}$, the anemometer height $[\mathrm{m}], Z_{0}$ the surface roughness length $[\mathrm{m}]$.

Turbine power output at standard air density is calculated by:

$$
P_{W T G}=\left(\frac{\rho}{\rho_{0}}\right) \cdot P_{W T G, S T P}
$$

where, $P_{W T G}$ is wind turbine power output $[\mathrm{kW}], P_{T W G, S T P}$ the wind turbine power output at standard temperature and pressure [kW], $\rho$ the actual air density $\left[\mathrm{kg} / \mathrm{m}^{3}\right]$ and $\rho_{0}$ the air density at standard temperature and pressure $[1.225$ $\left.\mathrm{kg} / \mathrm{m}^{3}\right]$.

\subsection{Battery Storage}

Conventional batteries are included in this analysis. Hoppeche 6 OPzs 600 models were considered in this study $(2 \mathrm{~V}, 600 \mathrm{Ah})$. One battery cost is setting at $\$ 300$ with a replacement cost of $\$ 200$ and operation and maintenance is set at $\$ 5 /$ yr. 24 battery per strings ( $48 \mathrm{~V}$ ) were considered for six ( 0 , no battery, 1, 2, 3, 4 , or 5). Lifetime is set at 8 years and initial state of charge is $100 \%$. Technical parameters of the batteries are presented in Table 3 below.

The battery bank life is calculated by the following Equations [4]:

$$
R_{\text {batt }}= \begin{cases}\frac{N_{\text {batt }} * Q_{\text {lifetime }}}{Q_{\text {thrpt }}} & \text { If limited by throughput }\end{cases}
$$


Table 3. Technical parameters of the batteries.

\begin{tabular}{cc}
\hline Parameters & Value \\
\hline Nominal capacity & $600 \mathrm{Ah}$ \\
Round trip efficiency & $86 \%$ \\
Minimum state of charge & $30 \%$ \\
Float life & $20 \mathrm{yrs}$ \\
Lifetime throughput & $2072 \mathrm{kWh}$ \\
Suggested value & $2072 \mathrm{kWh}$ \\
Max. charge rate & $1 \mathrm{~A} / \mathrm{Ah}$ \\
Max. charge current & $122 \mathrm{~A}$ \\
\hline
\end{tabular}

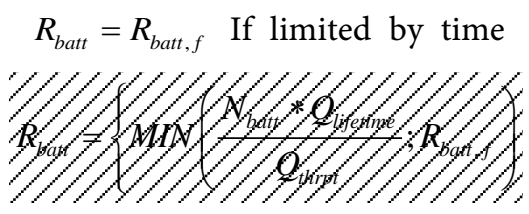

If limited by throughput and time $R_{b a t t}$ is the battery life, Nbatt the number of batteries in the battery, Qlifetime the lifetime throughput of a single battery, Qthrpt the annual battery throughput and $R_{\text {batt }}$, the battery float life.

\subsection{Power Converter}

A power converter/inverter was used in this study in order to maintain the energy flow between the $\mathrm{AC}$ and $\mathrm{DC}$ components in the system. $1 \mathrm{~kW}$ of the system requires an installation and replacement cost of \$ 300 and \$250 respectively. Operation and maintenance is set at $\$ 7 / \mathrm{yr}$. Four converter variants were considered in this model $(0,10,25$ and 75$)$. The lifetime of a converter is estimated at 8 years with an efficiency of $85 \%$ while the capacity relative to the inverter is $100 \%$ with an efficiency of $85 \%$.

\subsection{Economics and Constraints}

Lifetime project is considered at 25 years, with an annual real interest rate of $6 \%$, there is no capacity shortage penalty in Comoros. System fixed operations and maintenance costs is $6500 \$ / y r$. Maximum annual capacity shortage is $0 \%$. Renewable output, is $50 \%$ for both solar and wind energy. It is important to notice that here is no cost subsidy available from Comoros government. In general, to optimize a system under Homer, the first thing to do is to choose the system components in the "Equipment to be considered" block and then give the input parameters of each component such as daily loads, resources renewables, converter, fuel cell and the optimization costs of each component. At the entrance, Homer needs the data economic as the real interest rate $(i)$ which is calculated according to the rate of inflation annual $(i)$ and the nominal interest rate [27]:

$$
i=\frac{i-f}{1+f}
$$


So, for the optimization of the system Homer needs the lifetime, the cost initial investment, the cost of replacement, maintenance and labor each component to calculate the Net Cost of the Project (NPC) and the Cost of Energy (COE) of the system to meet the demand of the load. The NPC is calculated by the following relation [28]

$$
\mathrm{NPC}=\sum_{N=1}^{N=t} f_{d, N}\left(C_{\text {cap }}+C_{\text {remp }}+C_{\text {main }}+C_{m_{-} 0}\right)
$$

where $C_{\text {cap }}, C_{\text {remp }}, C_{\text {main }}$ and $C_{m_{-} 0}$ represent respectively the costs of capital, replacement, maintenance, labor, $\mathrm{t}$ the life time of the project and $f_{d, N}$ a calculated coefficient from the following relation [28]:

$$
f_{d, N}=\frac{1}{(1+i)^{N}}
$$

With $N$ represent, the year the project was developed. Homer calculates the cost of energy (COE) of the overall system [28]:

$$
\mathrm{COE}=\frac{A C_{T}}{E_{\text {charge }}}
$$

where $E_{\text {charge }}$ is the main load of the model and $A C_{T}$ is the total cost of the component. $A C_{T}$ is calculated by [28]:

$$
A C_{T}=\sum\left(C_{\text {acap }}+C_{\text {aremp }}+C_{\text {amain }}+C_{m_{-} 0}\right)
$$

\section{Results and Discussions}

\subsection{Sensitivity Results}

In this investigation, three sensitivities variables (global solar irradiation, wind speed and diesel fuel price) are considered in this analysis. For each of the sensitivity values, HOMER simulates all the systems in their respective search space. Indeed, an hourly time series simulation for every possible system type and configuration is done for one-year period. A feasible system is defined as a solution or hybrid system configuration that is capable of meeting the load. In the other hand, HOMER eliminates all infeasible combinations and ranks the feasible systems according to increasing net present cost (NPC) [29] [30] [31] [32]. In this study, five cases of global solar radiation average of $\left(5.29 \mathrm{kWh} / \mathrm{m}^{2} / \mathrm{d} ; 7.5\right.$ $\mathrm{kWh} / \mathrm{m} / \mathrm{d} ; 8 \mathrm{kWh} / \mathrm{m} / \mathrm{d} ; 8.5 \mathrm{kWh} / \mathrm{m} / \mathrm{d}$ and $9 \mathrm{kWh} / \mathrm{m} / \mathrm{d})$, wind speed $(4.92 \mathrm{~m} / \mathrm{s}, 5$ $\mathrm{m} / \mathrm{s} ; 5.5 \mathrm{~m} / \mathrm{s} ; 6 \mathrm{~m} / \mathrm{s}$ and $6.50 \mathrm{~m} / \mathrm{s})$ and diesel fuel price of $(0.79 \$ / \mathrm{L} ; 0.85 \$ / \mathrm{L} ; 0.89$ $\$ / \mathrm{L} ; 0.95 \$ / \mathrm{L}$ and $0.99 \$ / \mathrm{L}$ ) were used as a sensitivity variable. A total of 144 sensitivity cases were tested with each of the system configuration for 5760 simulations. Total simulation time was $3 \mathrm{~h} 59 \mathrm{mn}$ for an ACER aspire type V3-771 $\mathrm{G}$ Intel Core i3 personal computer with $2.3 \mathrm{GHz}$ of frequency.

The optimization results show that various optimal system types (OST) are displayed as functions of different sensitivity parameters. On the other hand, wind speed and solar irradiation data are presented for identification of system configuration for various locations around the site of study. 
Figure 5 and Figure 6 combined with Table 4, explain the global financial situation of the study. Figure 5 shows that capital cost for wind turbine is set at 5192 \$ while for the PV it is set at 24,794 \$ with 20,087 \$ for the battery cost and $3895 \$$ for converter and 16,880 \$ for diesel generator. Capital system cost is set at $46,400 \$$. Total net present cost of the system is set at 70,848 $\$$. Levelized COE is set at $0.241 \$ / \mathrm{kWh}$ with an operating cost of $1912 \$ / \mathrm{yr}$.

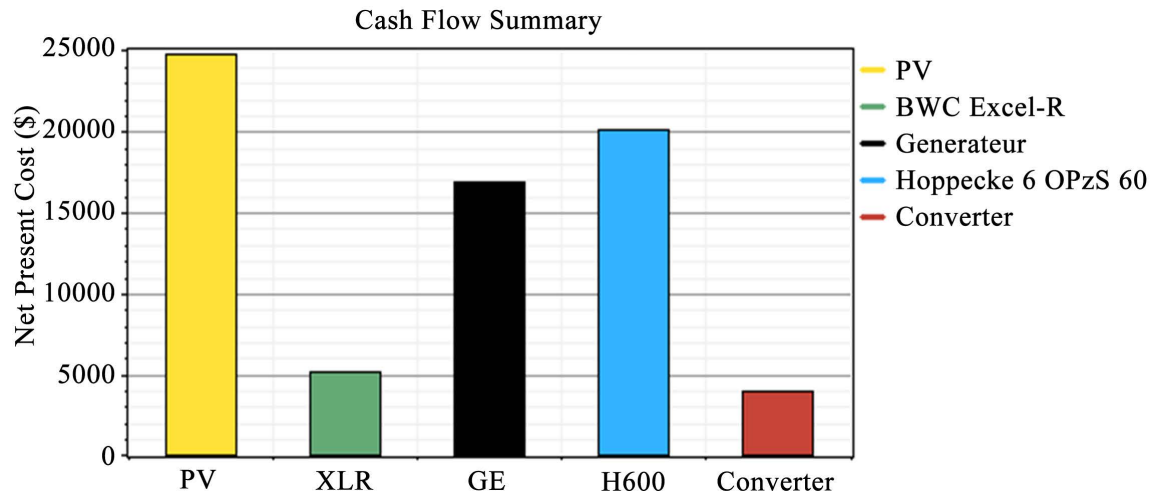

Figure 5. Cash flow cost summary.

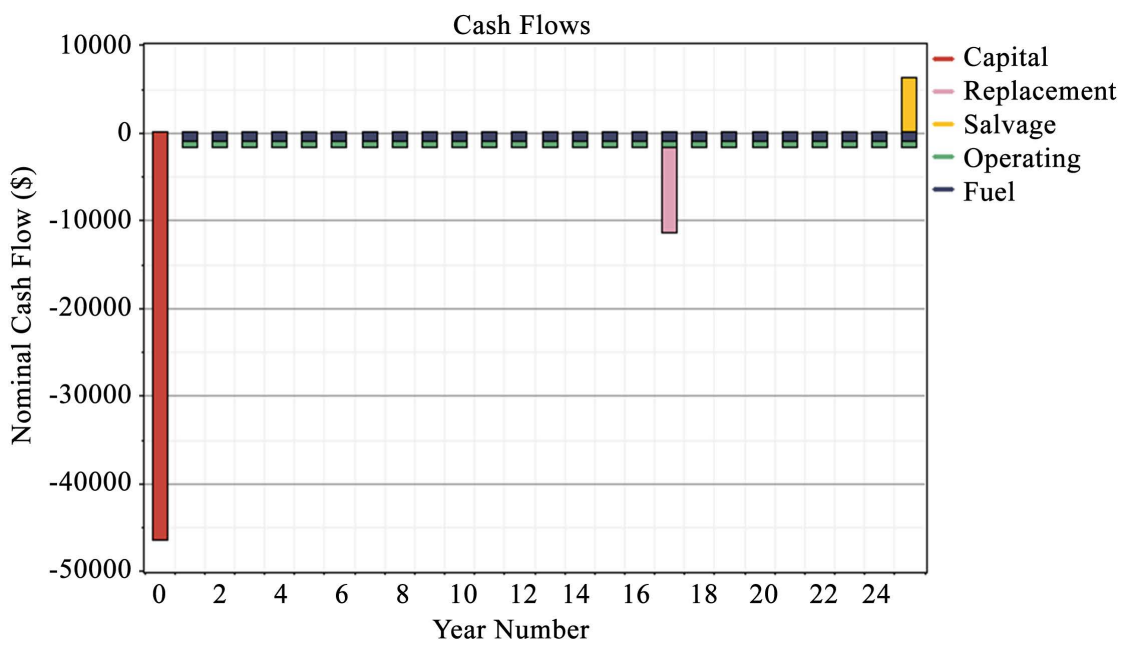

Figure 6. Cash flow cost of the project.

Table 4. Technical parameter.

\begin{tabular}{ccccccc}
\hline Components & $\begin{array}{c}\text { Capital } \\
(\$)\end{array}$ & $\begin{array}{c}\text { Replacement } \\
(\$)\end{array}$ & $\begin{array}{c}\mathrm{O} \text { and } \mathrm{M} \\
(\$)\end{array}$ & $\begin{array}{c}\text { Fuel } \\
(\$)\end{array}$ & $\begin{array}{c}\text { Salvage } \\
(\$)\end{array}$ & $\begin{array}{c}\text { Total } \\
(\$)\end{array}$ \\
\hline PV & 20,000 & 0 & 4794 & 0 & 0 & 24,794 \\
BWC Excel-R & 5000 & 0 & 192 & 0 & 0 & 5192 \\
Generator & 4000 & 0 & 1764 & 11,530 & -414 & 16,880 \\
Hoppeck 6 O PzS 600 & 14,400 & 3687 & 3068 & 0 & -1068 & 20,087 \\
Converter & 3000 & 0 & 895 & 0 & 0 & 3895 \\
System & 46,400 & 3687 & 10,712 & 11,530 & -1482 & 70,848 \\
\hline
\end{tabular}


Figure 6 shows the cash flow for the system. Each bar in the graph represents either total expenditures or total revenues for a year. The first bar, of year zero, shows the investment cost of the system $(46,400 \$)$. A negative value represents an expense, such as cost of component replacement or operation and maintenance $(\mathrm{O} \& \mathrm{M})$. A positive value represents a recipe, which may be the sale of electricity or the resale of components to the dismantling of the system at the end of the life of the project. At 17 years the battery and the converter must be replaced as shown in the figure with the negative bar. The project with a lifetime of 25 years will begin to be profitable which is explained by the positive bar (salvage) after 25 years.

Figure 7 shows the production details and annual electricity consumption of the system. Annual electricity production is set at $52,637 \mathrm{kWh} / \mathrm{yr}$ distributed as follow-up: $36,192 \mathrm{kWh} / \mathrm{yr}$ for PV array production at $69 \%$ of contribution, and $14,374 \mathrm{kWh} / \mathrm{yr}$ for wind at $27 \%$ of contribution and $2071 \mathrm{kWh} / \mathrm{yr}$ for diesel generator at $4 \%$ of contribution. As shown in Figure 7, PV array electricity production is high than that of others $69 \%$ due to the availability of a high solar in the rural area that exceeds $6 \mathrm{~kW}$. From May to September, we notice a high production of solar electricity because of a high penetrability solar radiation in this period. In the other hand, we notice that telecommunications towers load annual consumption is $22,958 \mathrm{Wh} / \mathrm{yr}$, the excess electricity $28,525 \mathrm{kWh} / \mathrm{yr}$ must be storage with a levelized cost of $0.241 \$ / \mathrm{kWh}$.

Figures $8(\mathrm{a})$-(c) represents an optimal system type provides that a system will be optimal at certain wind speed and global solar radiation. Figure 8(a) presents the total net present cost (NPC) of the system considering a diesel price fixed at 0.79 \$ L . (NPC) varied from 58,171 \$ and takes high value of 67,684 \$. In this case Wind/PV/GE/Battery hybrid system is dominant with high cost while Wind/ PV/Battery hybrid system is might be suitable with low total (NPC) value of 58,161 \$. All these depend of global solar and wind speed value.

Figure 8 (b) presents the Total Net present cost for Diesel Price fixed at 0.85 $\$ / \mathrm{L}$. It is important to notice that more Diesel price increases more hybrid system PV/Battery appears in the system and Wind/PV/GE/Battery disappears because of the high price of the fuel. Hybrid system Wind/PV/Battery becomes economically feasible. Figure 8 (c) justifies it because of the dominance of the hybrid system Wind/PV/Battery for a Diesel price fixed at 0.99 \$/L.

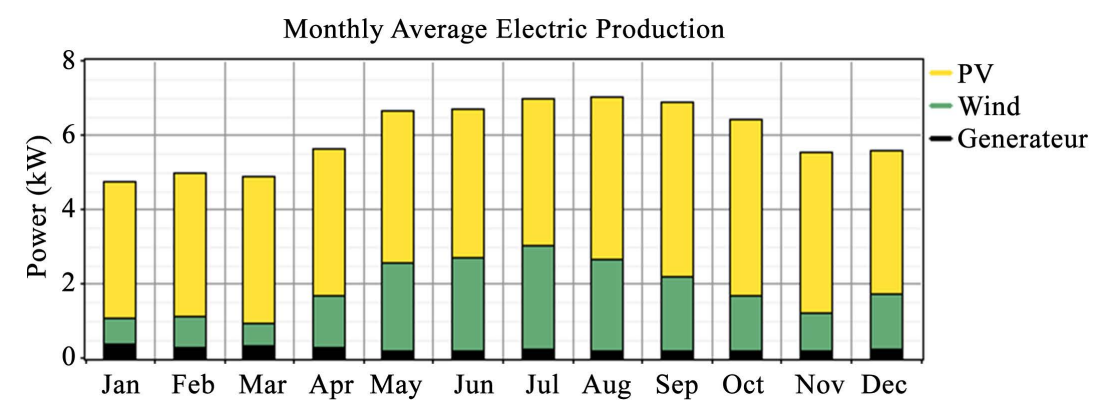

Figure 7. Monthly average electric productions. 


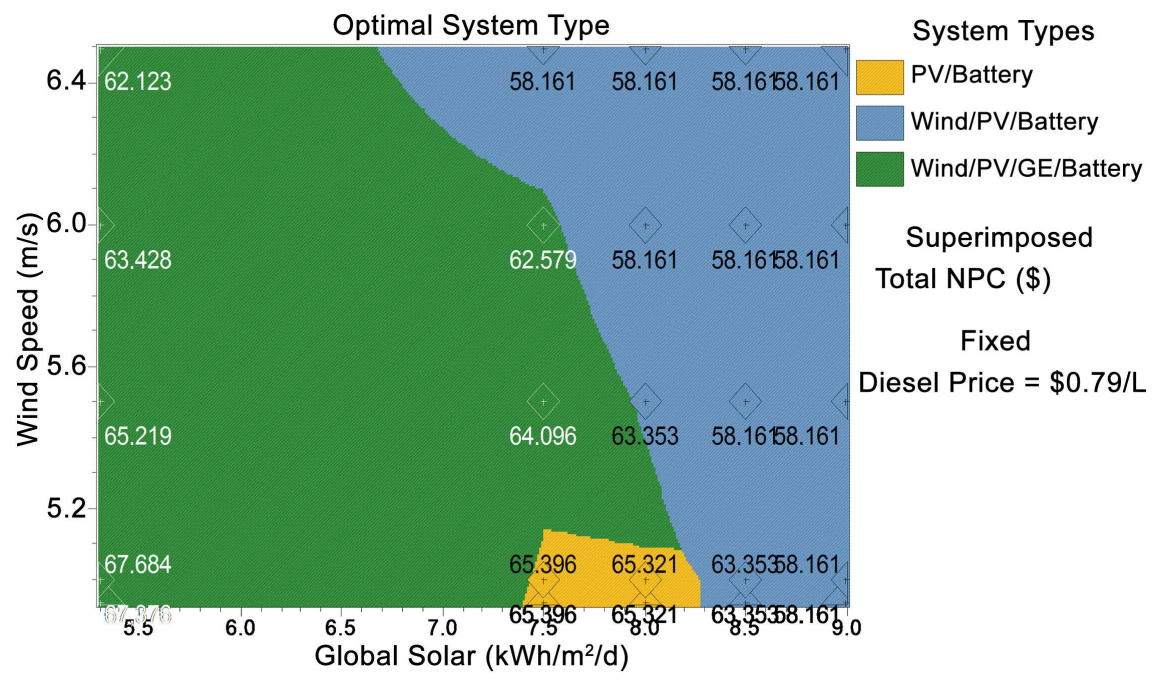

(a)

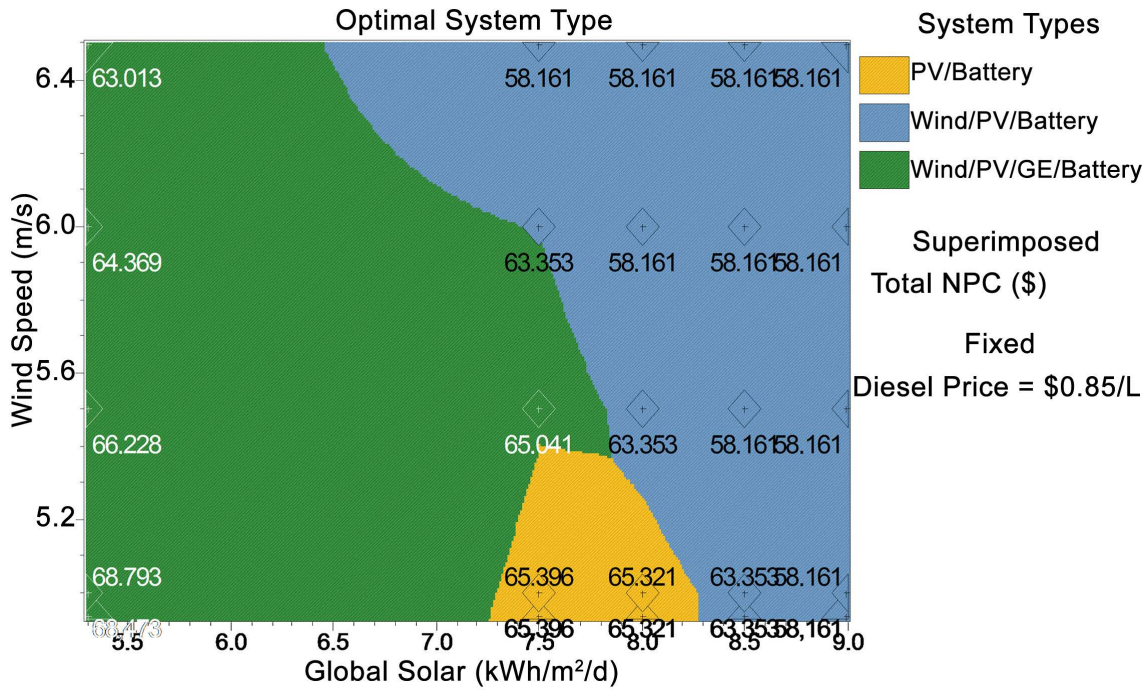

(b)

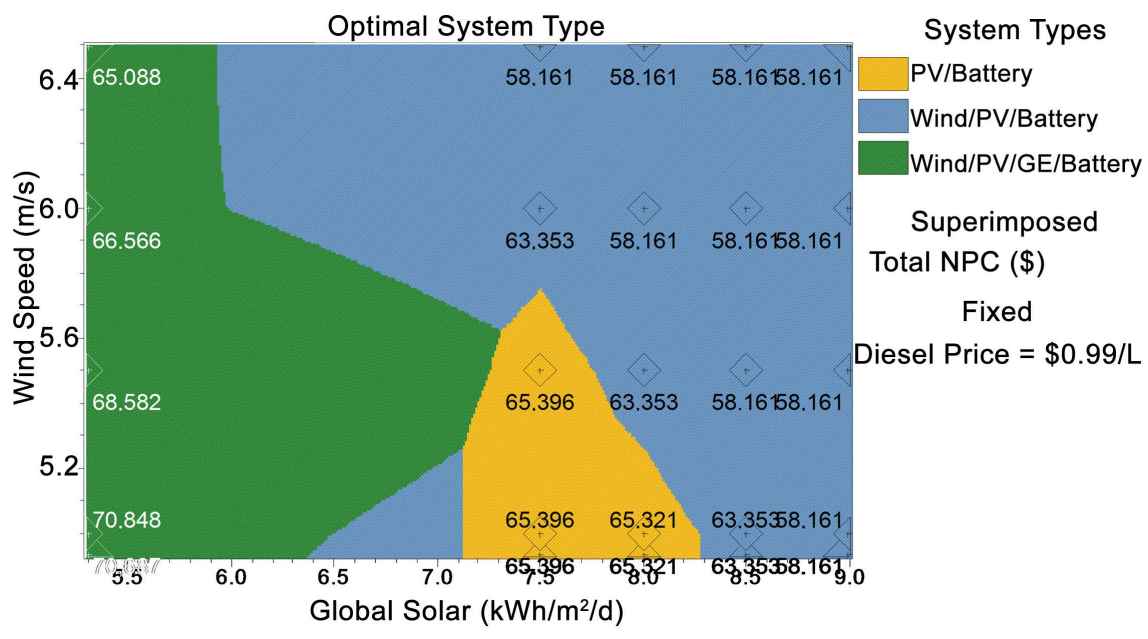

(c)

Figure 8. (a) Total net present cost for diesel price $=0.79 \$ / \mathrm{L}$; (b) total net present cost for diesel price $=0.85 \$ / \mathrm{L}$; (c) total net present cost for diesel price $=0.99 \$ / \mathrm{L}$. 
Levelized Cost of Energy (COE) is presented in Figures 9(a)-(c) it expresses the energy price of the kilowatt hour in American dollar. This parameter helps to make choice for different given hybrid energy system combination. Figure 9(a) presents the different feasibility hybrid system when global solar and diesel price vary with a wind speed fixed at $4.92 \mathrm{~m} / \mathrm{s}$. In this figure we distinguish three kinds of hybrid energy system combination. Wind/PV/GE/Battery hybrid energy system shows that Livelized Cost of Energy increases with increasing of diesel price and take value of $0.231 \$ / \mathrm{kWh}$ for Diesel Price $=0.79 \$ / \mathrm{L}$ to 0.241 $\$ / \mathrm{kWh}$ for diesel price of $0.79 \$ / \mathrm{L}$. On the other hand, PV/Battery hybrid system energy takes about constants value of $0.223 \$ / \mathrm{kWh}$ for a global solar from $7.44 \mathrm{kWh} / \mathrm{m}^{2} / \mathrm{d}$ to $8.24 \mathrm{kWh} / \mathrm{m}^{2} / \mathrm{d}$. Beyond this last value of global solar Win/ PV/Battery hybrid system take the low value of $0.198 \$ / \mathrm{kWh}$ and becomes suitable hybrid energy system.

Figure 9(b) presents Livelized Cost of Energy for a fixed wind speed of 5.5 m/s. A comparison with Figure 9(a) shows that hybrid energy system PV/Battery continues to disappear with increasing wind speed, so this combination is not advantageous for hybrid system. In the other hand, the Wind/PV/Battery is very advantageous economically with a Livelized Cost of energy of $0.198 \$ / \mathrm{kWh}$. Figure 9(c) shows that for a fixed wind speed of $6.5 \mathrm{~m} / \mathrm{s}$ we notice that PV/Battery hybrid energy system disappears completely and combination Wind/PV/Battery take the lead and becomes advantageous with the same value of $0.198 \$ / \mathrm{kWh}$. In this configuration increasing the wind speed value helps lower the price of energy invoice in order to satisfy customers and save diesel fuel. Telecommunications towers can be run without any doubt at $100 \%$ renewable energy when the wind speed reaches to $6.5 \mathrm{~m} / \mathrm{s}$. Indeed, more the wind speed is very high, more the contribution in renewable energies becomes advantageous and the hybrid system works well with a storage energy in the batteries for a subsequent supply. Wind/PV/battery system is more suitable.

Figure 10 présents total electrical production of energy by year for a fixed diesel price of $0.79 \$ / \mathrm{L}$ for renewable and no renewable energy production. Considering a superimposed Livelized Cost of energy, total electrical production energy varies from $40,000 \mathrm{kWh} / \mathrm{yr}$ to $90,000 \mathrm{kWh} / \mathrm{yr}$ depending on global solar and wind speed. On the other hand, for low value of wind speed, electrical production energy takes low values and increasing with high value of wind speed because of the important of wind energy production. It is important to notice that more wind speed become important more Livelized cost of energy decreases. Livelized cost of energy varies from $0.231 \$ / \mathrm{kWh}$ to $0.198 \$ / \mathrm{kWh}$ and take the same value beyond global solar of $8 \mathrm{kWh} / \mathrm{m}^{2} / \mathrm{d}$. A high value of total electrical production $(90,000 \mathrm{kWh} / \mathrm{yr})$ explains that all energy resources of the hybrid system are present (Wind/PV/GE) with a storage in the battery tank while a low value of annual total electrical production (40,000 to $45,000 \mathrm{kWh} / \mathrm{yr})$ shows that the hybrid energy system is dominated by fossil fuels with a storage in the battery tank. The maximum annual production is significant for a large high value of wind speed that exceeds $5.6 \mathrm{~m} / \mathrm{s}$ for a range of values from $60,000 \mathrm{kWh} / \mathrm{yr}$ to 


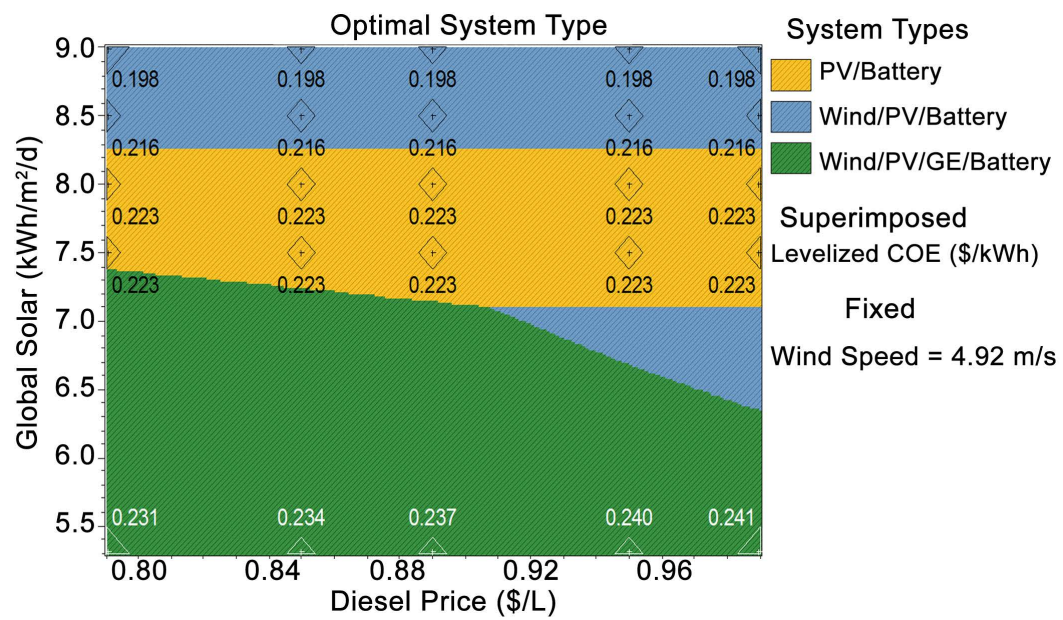

(a)

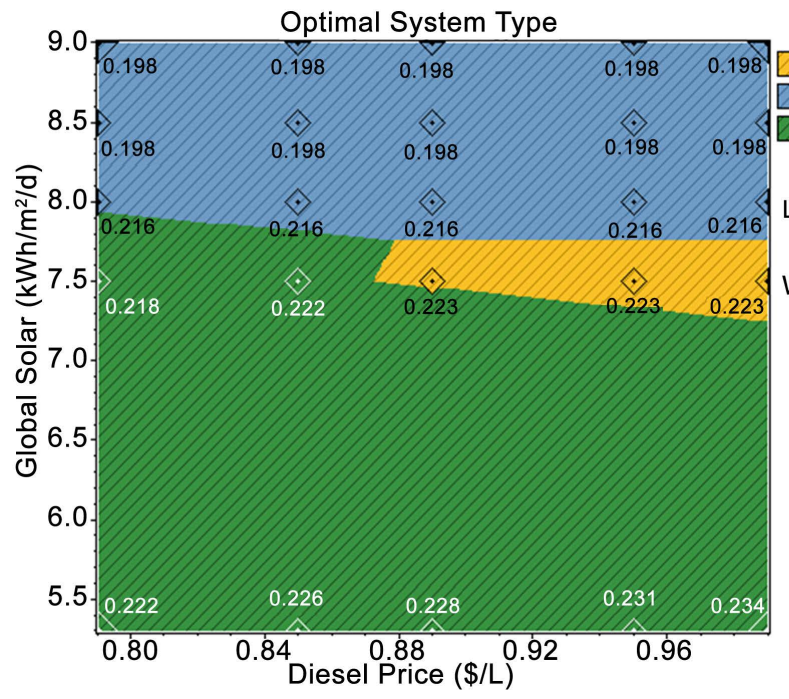

System Types $\square$ PV/Battery Wind/PV/Battery 7 Wind/PV/GE/Battery

Superimposed Levelized COE $(\$ / \mathrm{kWh})$ Fixed Wind Speed $=5.5 \mathrm{~m} / \mathrm{s}$

(b)

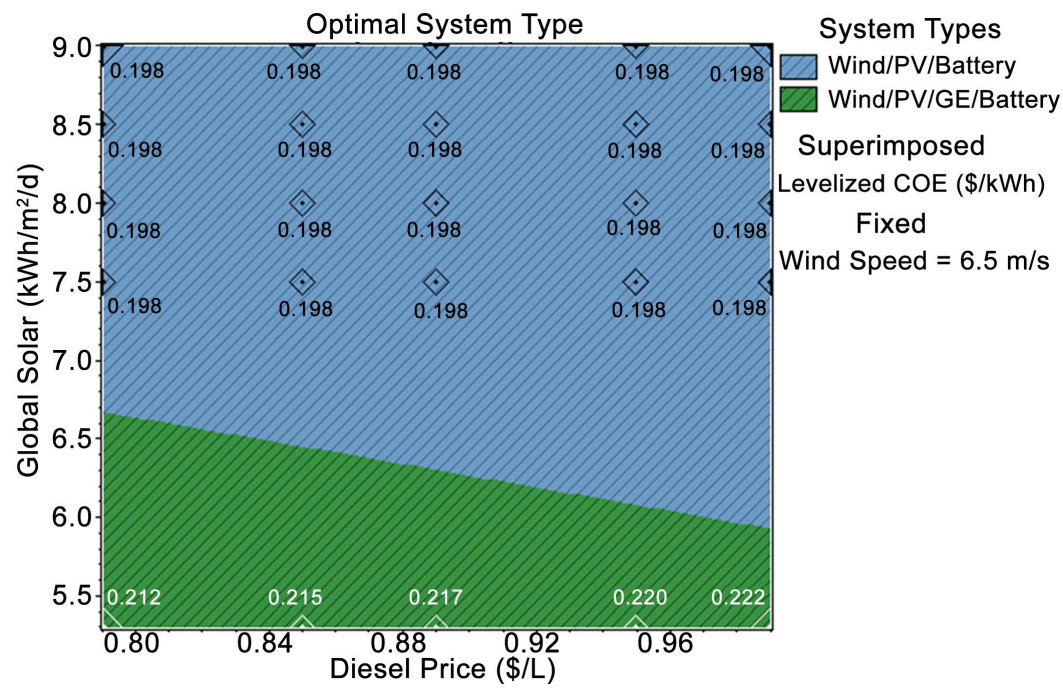

(c)

Figure 9. (a) Levelized COE for wind speed $=4.92 \mathrm{~m} / \mathrm{s}$; (b) levelized COE for wind speed $=5.5 \mathrm{~m} / \mathrm{s} ;$ (c) levelized COE for wind speed $=6.5 \mathrm{~m} / \mathrm{s}$. 


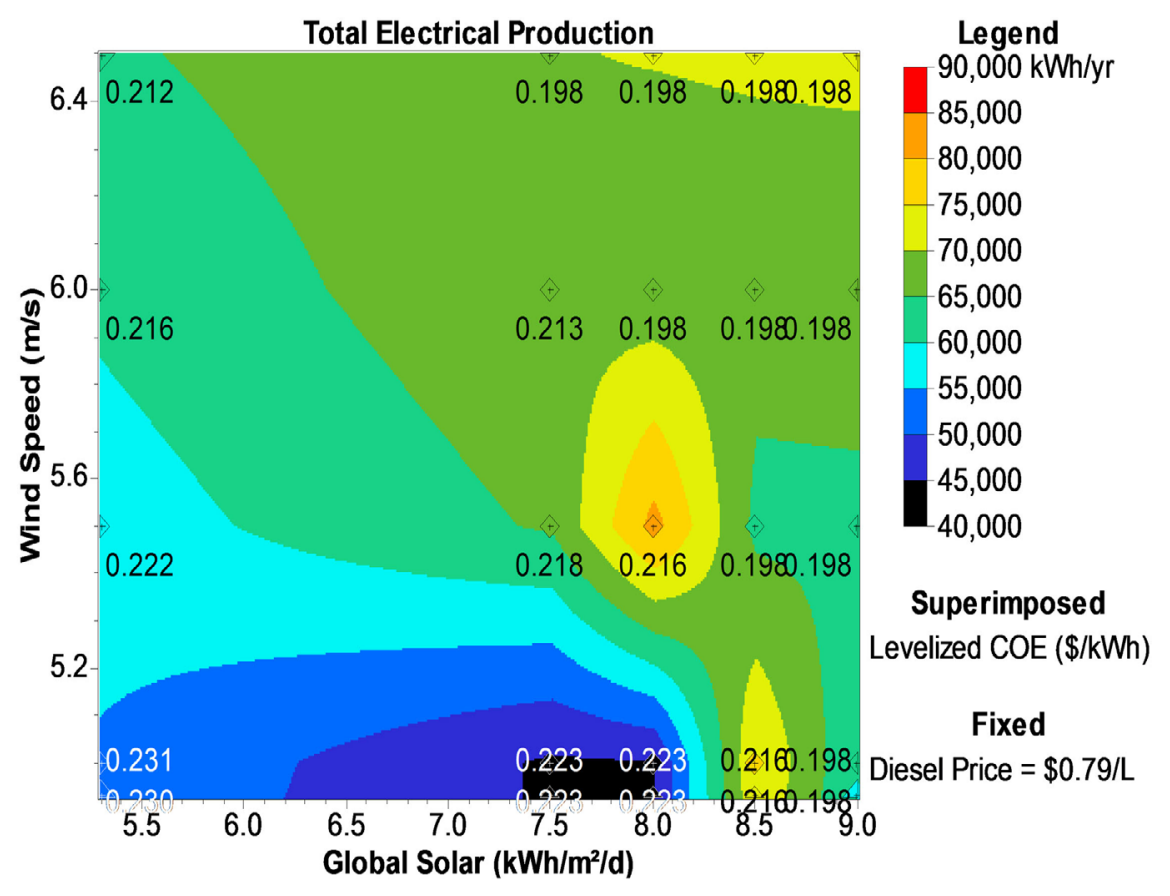

Figure 10. Total annual production energy for a diesel price of 0.79 \$L.

$65,000 \mathrm{kWh} / \mathrm{yr}$. In this case we see that for a large value of wind speed, the cost of energy decreases sharply and take the value of $0.198 \$ / \mathrm{kWh}$. This is justifies the domination of the hybrid system by renewable energy resources.

Figure 11 presents the same phenomenon as in the previous case (see Figure 10 ) with a fixed diesel price of $0.99 \$ / L$. In this situation, maximum energy produced is located in the center vein of the curve (global solar radiation $7.5 \mathrm{kWh} / \mathrm{m}^{2} / \mathrm{d}$ and wind speed $6 \mathrm{~m} / \mathrm{s}$ ) and divides towards the exit of the curve. The amount of production of the hybrid energy depends on several meteorological parameters data which influence them. Indeed, for a high price of diesel, renewable energy resources take the over of hybrid energy system. In the other hand, we observe that for a wind speed over $5.6 \mathrm{~m} / \mathrm{s}$, hybrid energy system work well and produces more between $65,000 \mathrm{kWh} / \mathrm{yr}$ and 90,000 kWh/yr.

\subsection{Optimization}

The best choice of the hybrid system is defined by sensitivity parameters on which characterize the optimization results. The best optimization results are selected by a PV/Wind/Gens/battery system with a diesel price of $0.79 \$ / \mathrm{L}$ for a global solar irradiation of $5.29 \mathrm{kWh} / \mathrm{m}^{2} / \mathrm{d}$ and a wind speed of $5.6 \mathrm{~m} / \mathrm{s}$. Indeed, the power of photovoltaic panels is $25 \mathrm{~kW}$ for a power Gens of $10 \mathrm{~kW}$ and a wind of $7.5 \mathrm{~kW}$ DC. String size of 24 batteries was used for 4 strings in parallel, with a bus voltage of $48 \mathrm{~V}$ have been detected. Converter and rectifier powers are $10 \mathrm{~kW}$ for each one. Initial Capital is 39,200 \$ and operating costs is set at 1793 $\$ / y r$. The Total Net Capital Cost is 62,123 \$, and diesel price is set at $1159 \mathrm{~L}$ for operating of $878 \mathrm{hrs} / \mathrm{yr}$ for Gens. Livelized cost is $0.212 \$ / \mathrm{kWh}$ and cash flow 
show that, battery replacement must be done after 15 years. Cost summary shows that, total cost of PV, wind, diesel Gens, battery, converter, others and total system are 24,794 \$; 5192 \$; 17,650 \$; 10,594 \$; 3895 \$ and 62,123 \$ respectively. Monthly average electric production shows that PV array must produce $36,191 \mathrm{kWh} / \mathrm{yr}$ for $56 \%$ of operating and Wind turbine of $25,420 \mathrm{kWh} / \mathrm{yr}$ for $40 \%$. Diesel Generator average electric production is set at $2636 \mathrm{kWh} / \mathrm{yr}$ for $4 \%$ of operating. Therefore $64,247 \mathrm{kWh} / \mathrm{yr}$ was used at $100 \%$ of operation. The monthly distribution of the electricity produced in $\mathrm{kW}$ by the system show that, renewable sources energy (PV and Wind turbine system) works well for a large domination of $96 \%$ while the Gens system works with only $4 \%$. The peak $(3.8$ $\mathrm{kW}$ ) load is met between May and September where demand is greater. Greenhouse gases emissions are summarized in Table 5 for more details about global gases emissions for hybrid system.

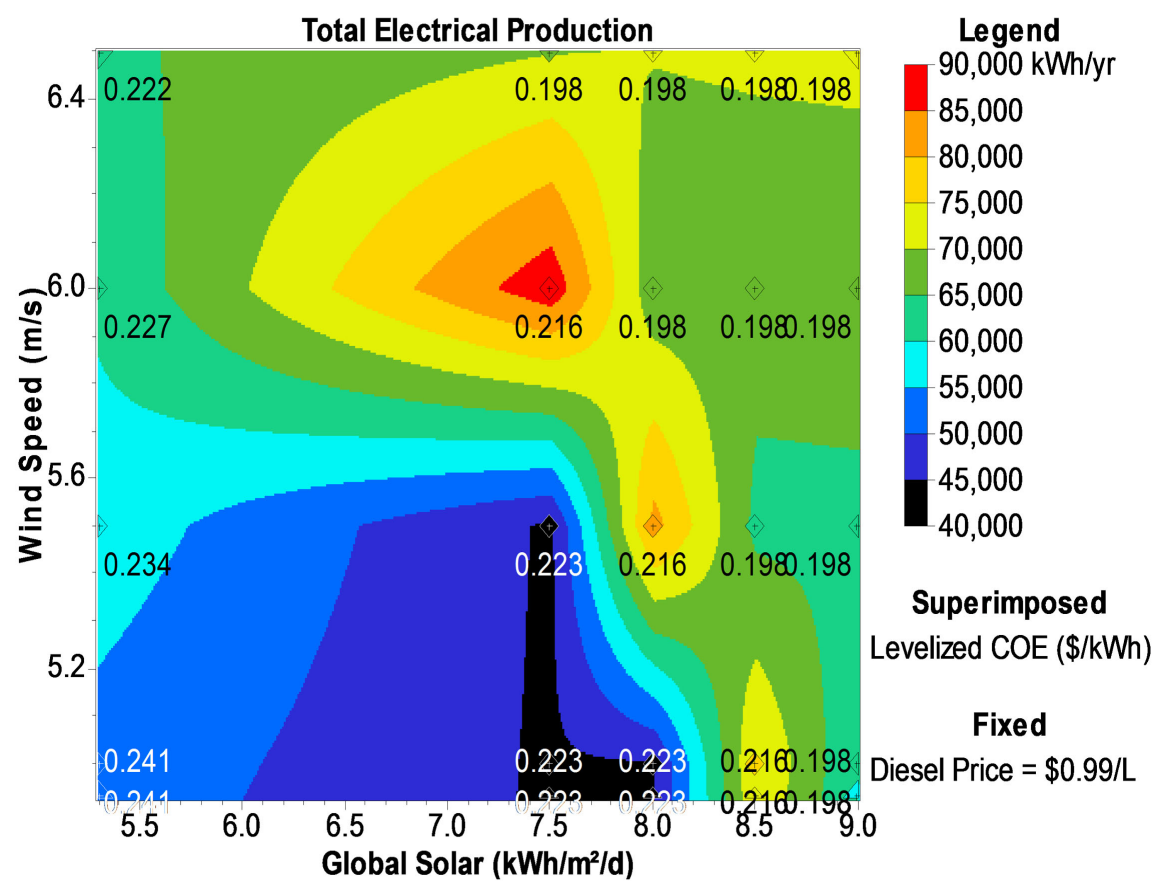

Figure 11. Total annual production energy for a diesel price of $0.99 \$ / \mathrm{L}$.

Table 5. Greenhouse gases for diesel and hybrid systems.

\begin{tabular}{cc}
\hline Pollution & Emission factor $(\mathrm{kg} / \mathrm{yr}$ of fuel $)$ \\
\hline Carbone monoxide & 7.54 \\
Carbone dioxide & 3.053 \\
Unburned hydrocarbons & 0.835 \\
Particulate matter & 0.568 \\
Nitrogen oxides & 67.2 \\
Sulfur dioxide & 6.13 \\
Total & 85.32 \\
\hline
\end{tabular}




\section{Conclusions}

In the present study PV-Wind-Diesel system for energy supply in remote areas applied for telecommunications towers in Comoros was conducted using HOMER software tool. Sensitivity parameters have been studied on this hybrid system especially for, wind speed, global solar irradiation and diesel price in order to optimize the system.

Several possible combinations have been ranked by the system priority in terms of cost and feasibility. Subsequently, the following system Win/PV/Battery was chosen as being the most reliable for such a combination with its energy efficiency for powering telecommunication towers. Indeed, we can retain that, Win/PV/Battery hybrid system takes the low value of cost of energy at 0.198 $\$ / \mathrm{kWh}$ and becomes suitable hybrid energy system. This cost of energy, is considered cheaper because currently in Comoros the cost of energy is about 0.31 $\$ / \mathrm{kWh}$. The best combination of hybrid systems reveals a combination of renewable energy hybrid systems with battery storage. We can note that for supplying telecommunications towers hybrid system, the cost of storage represents the greatest constraint on the overall cost of the system for large power plants, especially the use of intermittent renewable energy.

Among the advantages of such a system, Win/PV/Battery, we can mention the protection of the environment against climate warming with zero greenhouse gas emissions to fight against air pollution.

On the other hand, minimizing the cost of storage and optimizing its capacity is the main reason for the combination of Win/PV/Battery hybrid systems. This combination has been selected in this hybrid system for power supply for telecommunication towers and is more efficient in terms of cost and feasibility. All these configurations have a provision to sell excess electricity to the grid. It is important to notice that levelized cost of energy of all the renewable energy configuration is much lower than that included Diesel Gens set and battery-based configuration.

\section{Conflicts of Interest}

The authors declare no conflicts of interest regarding the publication of this paper.

\section{References}

[1] Mohamad, S.M.N., Zuraimy, A., Yanuar, Z.A. and Nor, A.M. (2016) Feasibility Analysis of Stand-Alone Renewable Energy Supply for Telecommunication Tower Using Homer. Applied Mechanics and Materials, 818, 223-227. https://doi.org/10.4028/www.scientific.net/AMM.818.223

[2] Niranjan, R.D., Bhim, S. and Tara, C.K. (2018) Load Profile of Telecom Towers and Potential Renewable Energy Power Supply Configurations. 2018 IEEE International Conference on Power Electronics, Drives and Energy Systems (PEDES), Chennai, 18-21 December 2018, 1-6.

[3] Olatomiwa, L., Saad, M., Ismail, M.S. and Moghavvemi, M. (2016) Energy Man- 
agement Strategies in Hybrid Renewable Energy System: A Review. Renewable and Sustainable Energy Reviews, 62, 821-835. https://doi.org/10.1016/j.rser.2016.05.040

[4] Aboudou, K.M. and El Ganoui, M. (2019) Design of a Hybrid System for Rural Area Electricity Supply in Comoros. Journal of Power and Energy Engineering, 7, 59-78. https://doi.org/10.4236/jpee.2019.72005

[5] Aboudou, K.M. and El Ganoui, M. (2017) Feasibility Study for the Generation of Electricity Using a Hybrid PV-Wind-Generator System in a Remote Area in Comoros. International Journal of Research and Reviews in Applied Science, 33, 23-36. https://www.arpapress.com/Volumes/Vol33Issue2/IJRRAS_33_2_02.pdf

[6] Fahad, M., Aboudou, K.M., Rakoto, J.O. and El Ganaoui, M. (2018) Design of a Hybrid System for the Power Supply of a Telecommunications Tower in the Comoros. International Symposium Francophone Energetics and Mechanics, Cotonou, 23-25 April 2018. https://hal.archives-ouvertes.fr/hal-01882293/document

[7] Aboudou, K.M. and El Ganaoui, M. (2017) Feasibility Study of Stand-Alone Hybrid Energy System for Implementation of Buildings in Rural Areas in Comoros. International Conference on Materials \& Energy \& Symposium ICAPM, Tianjin, 6-9 July 2017. http://www.icome.ecam-epmi.fr/img/Livret2017.pdf

[8] Aboudou, K.M., Maoulida, F. and El Ganaoui, M. (2018) PV-Wind Hybrid Energy System for Application of Buildings in Rural Areas in Comoros. International Conference on Materials and Energy, ICOME2018, San Sebastian, 30 April-4 May 2018. http://www.icome.ecam-epmi.fr/img/Livret2018.pdf

[9] Maoulida, F. and Aboudou, K.M. (2018) Modeling of a Type of Photovoltaic Module sx 150 bp for Power Generation. 6th International Conference for Renewable Energies (CIER-2018), Hammamet, 19-22 December 2018.

[10] Aboudou, K.M. and El Ganaoui, M. (2017) Design of a Hybrid System for Electricity Supply to the Mix Energetic. International Conference on Energy, Environment and Climate Change, ICEECC, Mauritius, 5-7 July 2017.

http://iceecc.org/registration.html https://www.uom.ac.mu/FOe/index.php/102-archives/conferences

[11] Maoulida, F., Aboudou, K.M. and El Ganaoui, M. (2021) Feasibility Study for a Hybrid Power plant (PV-Wind Energy-Diesel Storage) Connected to the Electricity Grid in the Comoros. International Conference on Materials \& Energy (ICOME 2021), Metz, 3-5 June 2021. http://www.icome.ecam-epmi.fr/

[12] Maoulida, F. (2018) Development of a Hybrid System of Generation of Energy in an Isolated Site for Telecommunications and Realization of a Solar Charge Regulator. Master, University from Antananarivo, Science and Technology, Physics and Application, supported on 7 June 2018.

http://biblio.univ-antananarivo.mg/pdfs/fahadMaoulida_PC_MAST_18.pdf

[13] Aziz, A.S. and Khudhier, S.A. (2017) Optimal Planning and Design of an Environmentally Friendly Hybrid Energy System for Rural Electrification in Iraq. American Journal of Applied Sciences, 14, 157-165. https://doi.org/10.3844/ajassp.2017.157.165

[14] Saima, I., Sadaqat, N., Shahid, M. and Nadjam-ul-Islam (2016) Techno-Economic Analysis of a Hybrid Grid-Connected/PV/Wind System in Pakistan. International Journal of Renewable Energy Research, 6, 1318-1327. https://ijrer.org/ijrer/index.php/ijrer/article/view/4537/pdf

[15] Godson, J., Karthick, M., Muthukrishnan, T. and Sivagamasundari, M.S. (2013) Solar PV-Wind Hybrid Power Generation System. International Journal of Advanced Research in Electrical Electronics and Instrumentation Engineering, 2, 5350-5354. 
http://www.ijareeie.com/upload/2013/november/5_SOLAR.pdf

[16] Tiago, T.S. and Luciana, M. (2016) Optimization of Energy Hybrid System for an Isolated Community in Brazil. International Journal of Renewable Energy Research, 6, 1476-1481. https://www.ijrer.org/ijrer/index.php/ijrer/article/view/4724/pdf

[17] Das, S. and Akella, A.K. (2018) Power Flow Control of PV-Wind-Battery Hybrid Renewable Energy Systems for Stand-Alone Application. International Journal of Renewable Energy Research, 8, 36-43. https://ijrer.org/ijrer/index.php/ijrer/article/view/6534/pdf

[18] Ceran, B., Hassan, Q., Jaszczur, M. and Sroka, K. (2017) An Analysis of Hybrid Power Generation Systems for a Residential Load. E3s Web Conferences, Energy and Fuels, 14, 1-10. https://doi.org/10.1051/e3sconf/20171401020

[19] Al-Nimr, M.A. and Qananba, K.S. (2018) A Solar Hybrid System for Power Generation and Water Distillation. Solar Energy, 171, 92-105. https://doi.org/10.1016/j.solener.2018.06.019

[20] Kohsri, S. and Plangklang, B. (2011) Energy Management and Control System for Smart Renewable Energy Remote Power Generation. Energy Procedia, 9, 198-206. https://doi.org/10.1016/j.egypro.2011.09.021

[21] Alturki, F.A. and Dayil, A.B. (2020) Techno-Economic Evaluation and Optimization of Grid Connected PV and Wind Generating System for Riadh City. Journal of Power and Energy Engineering, 8, 46-63. https://doi.org/10.4236/jpee.2020.812004

[22] Alsamamra, H.R. and Shoqeir, J.A.H. (2020) Assessment of Wind Power Potential at Eastern-Jerusalem, Palestine. Open Journal of Energy Efficiency, 9, 131-149. https://doi.org/10.4236/ojee.2020.94009

[23] El-Hefnawi, S.H. (1998) Photovoltaic Diesel-Generator Hybrid Power System Sizing. Renewable Energy, 13, 33-40. https://doi.org/10.1016/S0960-1481(97)00074-8

[24] Kusakana, K. and Vermaak, H.J. (2014) Hybrid Diesel Generator/Renewable Energy System Performance Modelling. Renewable Energy, 67, 97-102. https://doi.org/10.1016/j.renene.2013.11.025

[25] Aboudou, K.M. (2016) Rapport national du cadre réglementaire sur les énergies renouvelables aux Comores. Etat de lieu et possibilité d'amélioration, Juin 2016.

[26] Duffie, J.A. and Beckman, W.A. (1991) Solar Engineering of Thermal Processes. 2nd Edition, Wiley, New York. https://www.academia.edu/25940536/Solar_Engineering_of_Thermal_Processes

[27] Naik, V.V.K., Krishna, G.J. and Visali, N. (2018) Review of Optimal Integrated Control Strategies for Renewable Energy Based Micro Grid System. International Journal of Pure and Applied Mathematics, 118, 17-26. https://acadpubl.eu/jsi/2018-118-14-15/articles/15/3.pdf

[28] Kalinci, Y., Hepbasli, A. and Dincer, I. (2015) Techno-Economic Analysis of a Stand-Alone Hybrid Renewable Energy System with Hydrogen Production and Storage Options. International Journal of Hydrogen Energy, 40, 7652-7664. https://doi.org/10.1016/j.ijhydene.2014.10.147

[29] Elhadidy, M.A. and Shaahid, S.M. (1999) Feasibility of Hybrid (Wind + Solar) Power Systems for Dhahran, Saudi Arabia. Renewable Energy, 16, 970-976. https://doi.org/10.1016/S0960-1481(98)00344-9

[30] Elhadidy, M.A. and Shaahid, S.M. (1999) Optimal Sizing of Battery Storage for Hybrid (Wind + Diesel) Power Systems. Renewable Energy, 18, 77-86. https://doi.org/10.1016/S0960-1481(98)00796-4

[31] Shaahid, S.M. and Elhadidy, M.A. (1994) IBM pc-Based Data Acquisition System 
for Solar Radiation Station. Proceedings of the 40 th International Instrumentation Symposium (ISA), Vol. 40, 1-5 May 1994.

[32] Elhadidy, M.A. and Shaahid, S.M. (1994) Effect of Kuwait's Oil-Fire Smoke Cloud on Global Horizontal Irradiance at Dhahran, Saudi Arabia. Solar Energy, 52, 439-446. https://doi.org/10.1016/0038-092X(94)90121-H 